\title{
Occurrence of strawberry root and crown rot in Western Australia
}

\author{
H. Golzar ${ }^{\mathrm{A}, \mathrm{B}}$, D. Phillips ${ }^{\mathrm{A}}$ and S. Mack ${ }^{\mathrm{A}}$ \\ ADepartment of Agriculture and Food Western Australia, Locked Bag 4, Bentley Delivery Centre, \\ WA 6983, Australia. \\ ${ }^{B}$ Corresponding author. Email: hgolzar@agric.wa.gov.au
}

\begin{abstract}
A high incidence of root and crown rot of strawberries was observed in production districts in the Swan Coastal Plain north of Perth during 2005 and 2006. Fifty samples of affected and asymptomatic plants were collected randomly. Crown and roots of individual plants were examined and soil surrounding roots was tested for soilborne pathogens. Fusarium oxysporum f. sp. fragariae was consistently isolated from crowns and Phytophthora cactorum was detected from roots, crowns and soil as a major pathogen. Results of this study showed that several pathogens such as Pythium spp., Phoma spp., Rhizoctonia spp., Colletotrichum spp. and Macrophomina spp. were associated with the root and crown rot of strawberries.
\end{abstract}

Root and crown rots are important diseases of commercial strawberry crops. Several fungi have been reported as causal agents of strawberry crown and root rot, and they cause considerable yield reduction worldwide. The fungi Phytophthora spp., Verticillium spp., Fusarium spp. Gnomonia fragariae and Colletotrichum spp. are known to be important pathogens (D'Ercole et al. 1989; Tezuka and Makino 1991; Freeman et al. 1997; Maas 1998; Morocko et al. 2006). Strawberries are a high-value export crop that are grown in the temperate areas of Western Australia. Soilborne fungal pathogens are routinely controlled by soil fumigation, but plant death has recently been extremely high in some fumigated and non-fumigated strawberry fields.

During the surveys conducted in 2005 and 2006, a high incidence of strawberry death was observed in coastal districts up to $50 \mathrm{~km}$ north of Perth areas (Fig. 1). Mortality of Camarosa and Gaviota varieties of strawberry (Fragaria $\times$ ananassa) was between 0 and $60 \%$ in some strawberry fields. A total of 50 affected and asymptomatic plants and soil samples surrounding their roots was collected randomly from five fields. Roots were carefully washed under running tap water and the crown of each plant was dissected lengthwise. Vascular discolouration of the crown and root rot was observed on $75 \%$ of the samples collected. Crowns and roots of affected and asymptomatic plants were surface-sterilised by immersion in a $1.25 \%$ aqueous solution of sodium hypochlorite for $1 \mathrm{~min}$, rinsed in sterile water and dried in a laminar flow cabinet. Pieces of root and crown were then separately placed on potato dextrose agar (PDA), water agar and selective media (P10VPH and P10VP) (Tsao and Guy 1977 ) and then incubated at $22 \pm 3^{\circ} \mathrm{C}$. Emerged fungal colonies were sub-cultured on carnation leaf agar, PDA and V-8 juice agar and incubated at $25^{\circ} \mathrm{C}$ with a $12 \mathrm{~h}$ dark and light cycle. The soil samples were baited with cotyledons of Eucalyptus sieberi for isolation of Pythium and Phytophthora species (Marks and Kassaby 1974). Growth rate, colony morphology

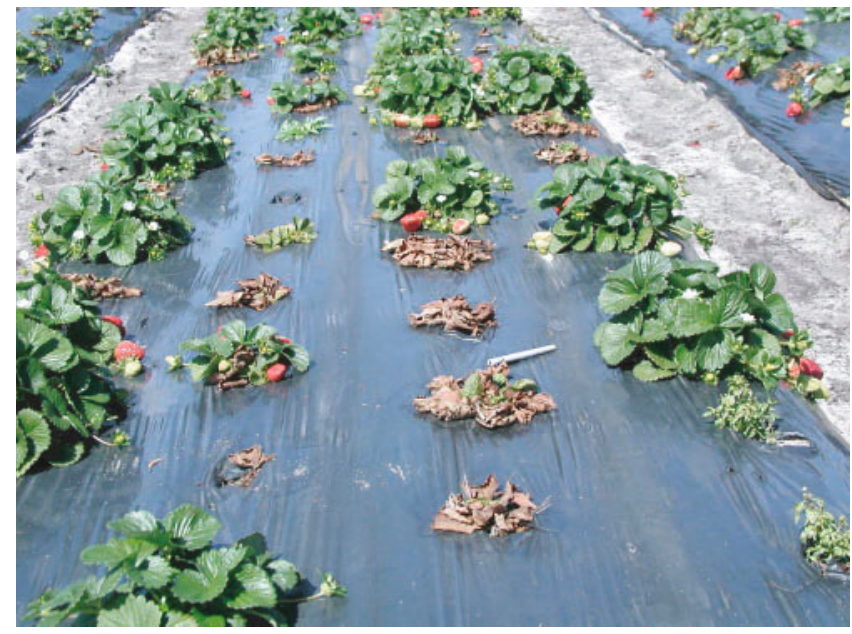

Fig. 1. Strawberry plants severely affected by root and crown rot in a field north of Perth.

and morphological characteristics of the fungi isolated were determined.

The pathogenicity of Fusarium isolates was tested on Fragaria $\times$ ananassa $\mathrm{cv}$. Camarosa, Lycopersicon lycopersicum cv. Petula and Cucumis sativus (Lebanese cucumber) in a glasshouse experiment. Strawberry runners and 4-week-old seedlings of tomato and cucumber were inoculated by dipping the roots in a spore suspension $\left(10^{5}\right.$ spores $\left./ \mathrm{mL}\right)$ before planting. Controls were dipped in tap water using the method of Stall and Walter (1965). Fusarium isolates used were pathogenic on the strawberry runners but non-pathogenic on the tomato and cucumber plants tested. Pathogenicity of the Phytophthora cactorum isolates was tested by inoculating wounded and nonwounded strawberry crowns and roots with 5-mm mycelial plugs 

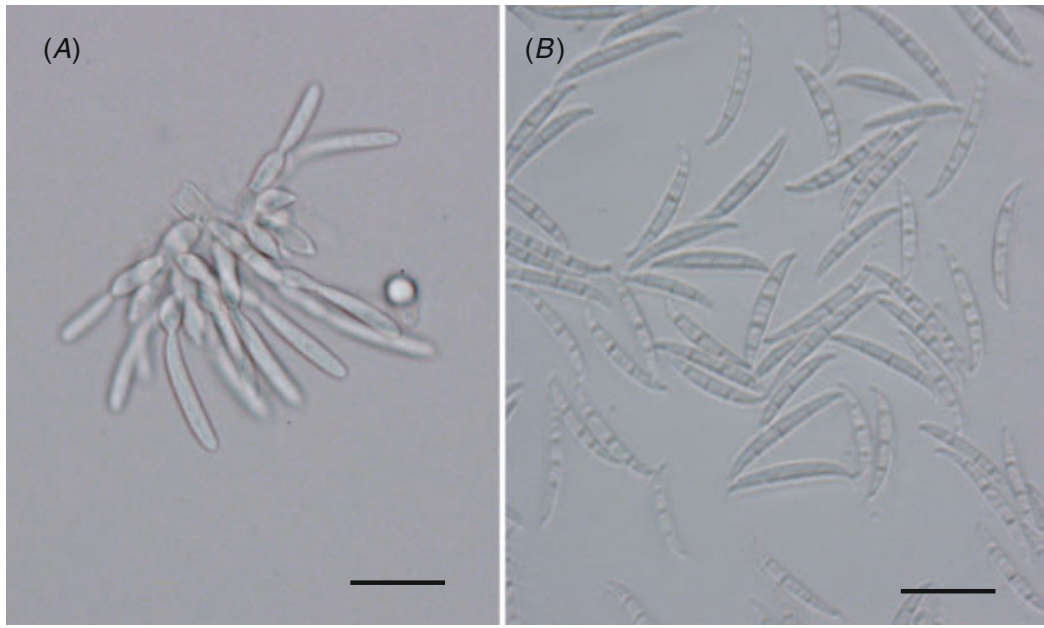

Fig. 2. F. oxysporum f. sp. fragariae. (A) Sporodochia with monophialides macroconidia and $(B)$ mature macroconidia. Scale bars $=25 \mu \mathrm{m}$.
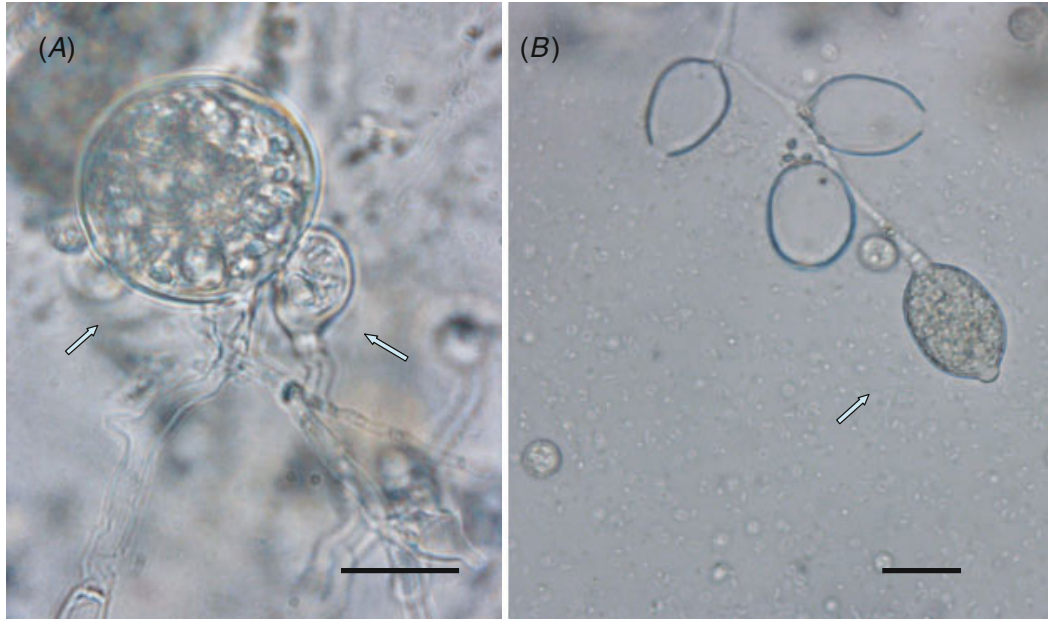

Fig. 3. Phytophthora cactorum. (A) Oogonia with paragynous antheridia and $(B)$ sporangiophore and sporangia. Scale bars $=20 \mu \mathrm{m}$.
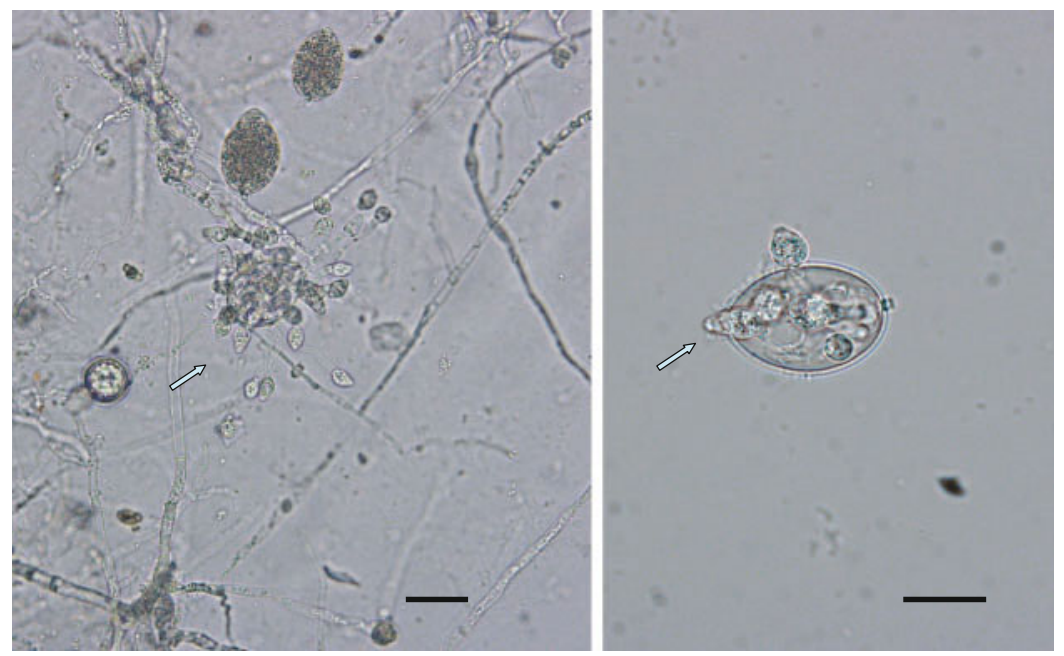

Fig. 4. Phytophthora cactorum. Germinated and proliferated sporangia are indicated by arrows. Scale bars $=20 \mu \mathrm{m}$. 
from the 7-day-old V-8 juice agar culture. Strawberry runners were planted in the sterilised potting mix and four mycelial plugs per pot were in direct contact with the crown and roots for each treatment. Control plants were tested correspondingly, but with sterile agar plugs. Root rot and vascular discolouration of the crown tissues were evident on the inoculated plants and not on the controls after 3 weeks. Pathogenicity, symptoms and morphological characteristics of the reisolated fungi from strawberry runners were confirmed following Koch's postulates.

During the survey, a high incidence of crown rot with typical infection by Fusarium spp. discolouration was observed. Fusarium oxysporum f. sp. fragariae was consistently isolated from the samples tested (Fig. 2). This fungus has been reported in Queensland and Japan as an important pathogen of strawberry (Winks and Williams 1965; Maas 1998). Phytophthora cactorum was detected from crown, root and soil samples (Figs 3 and 4). Phytophthora cactorum has not been reported causing crown or root rot on strawberry in Western Australia. However, there is a record of this fungus on the other hosts in the culture collection of Department of Agriculture and Food Western Australia (WAC). Phytophthora cactorum causes lather rot of fruit and crown rot of strawberry in Australia, the USA, Europe and parts of Asia and Africa (Washington et al. 1999; Eikemo et al. 2004). In this study, F. oxysporum f. sp. fragariae and $P$. cactorum were often isolated independently or in combination with Pythium spp., Rhizoctonia spp., Colletotrichum spp. or Macrophomina spp.

Cultures of F. oxysporum f. sp. fragariae and P. cactorum have been deposited in the WAC as WAC 12708 and WAC 12984, respectively.

\section{Acknowledgements}

The authors would like to thank Dr Elaine Davison for scientific comments on the Phytophthora cactorum, Dr Manisha Shankar for reviewing of the manuscript and the Western Australia strawberry industry for financial support.

\section{References}

D’Ercole N, Nipoti P, Manzali D (1989) Research on the root rot complex of strawberry plants. Acta Horticulturae 265, 497-506.

Eikemo H, Stensvand A, Tronsmo AM, Klemsdal SS, Riisberg I, Bonants P (2004) Genetic variation between Phytophthora cactorum isolates differing in their ability to cause crown rot in strawberry. Mycological Research 108, 317-324. doi: 10.1017/S0953756204009244

Freeman S, Nizani Y, Dotan S, Sando T (1997) Control of Colletotrichum acutatum in strawberry under laboratory, greenhouse and field conditions. Plant Disease 81, 749-752. doi: 10.1094/ PDIS.1997.81.7.749

Maas JL (1998) ‘Compendium of strawberry diseases.' 2nd edn. (APS Press: St Paul, MN)

Marks GC, Kassaby FY (1974) Detection of Phytophthora cinnamomi in soils. Australian Forestry 36, 198-203.

Morocko I, Fatehi J, Gerhardson B (2006) Gnomonia fragariae, a cause of strawberry root rot and petiole blight. European Journal of Plant Pathology 114, 235-244. doi: 10.1007/s10658-005-5282-x

Stall RE, Walter JM (1965) Selection and inheritance of resistance in tomato to isolates of race 1 and 2 of the fusarium wilt organism. Phytopathology 55, 1213-1215.

Tezuka N, Makino T (1991) Biological control of Fusarium wilts of strawberry by nonpathogenic Fusarium oxysporum isolated from strawberry. Annals of the Phytopathological Society of Japan 57, 506-511.

Tsao PH, Guy SO (1977) Inhibition of Mortierella and Pythium in a Phytophthora isolation medium containing hymexazol. Phytopathology 67, 796-801.

Washington WS, Engleitner S, Boontjes G, Shanmuganathan N(1999) Effect of fungicides, seaweed extracts, tea tree oil, and fungal agents on fruit rot and yield in strawberry. Australian Journal of Experimental Agriculture 39, 487-494. doi: 10.1071/EA98164

Winks BL, Williams YN (1965) A wilt of strawberry caused by a new form of Fusarium oxysporum. Queensland Journal of Agricultural and Animal Sciences 22, 475-479.

Manuscript received 2 July 2007, accepted 11 October 2007 